iD https:/ orcid.org/0000-0003-3993-2182

\title{
Koncepcja podziału procesu karnego na dwie fazy - 50 lat później
}

\begin{abstract}
This paper aims to answer the question whether the concept of dividing a criminal trial into two phases is still useful now, more than half a century after its last broader analysis. It also attempts to solve some specific problems related to the said analysis. The starting point for the considerations contained in the paper was to look at the concept of a two-phase criminal trial as a purely procedural construction and thus to reject its functional link with any model of substantive criminal law. The first part of the paper discusses the history of the concept of a two-phase criminal trial, as well as some of the arguments put forward by its supporters and opponents. In the course of further deliberations, the focus is on searching for elements of the concept in the current legal status. The final part of the text deals with the question whether and, possibly, in what form the concept of division of jurisdictional proceedings should become an element of the Polish criminal procedure. This is followed by numerous and widely justified de lege ferenda conclusions.
\end{abstract}

Keywords: the concept of dividing the criminal trial into two phases, two-phase criminal trial, preliminary judgment, final judgment, horizontal validity of part of the judgment, independence of jurisdiction of the criminal court, measures of appeal, cassation, consensual proceedings, criminal proceedings, prohibited act, offence, offender

\section{Wstęp}

$\mathrm{Na}$ początku drugiej połowy XX w. wśród przedstawicieli doktryny prawa karnego procesowego różnych państw europejskich szczególne zainteresowanie budziła koncepcja podziału procesu karnego na dwie fazy, z których pierwsza byłaby poświęcona ustaleniu winy oskarżonego, a druga skupiałaby się wyłącznie na zastosowaniu wobec sprawcy właściwych środków reakcji karnej ${ }^{1}$.

${ }^{1}$ Szerzej A. Murzynowski: Refleksje na temat nauki procesu karnego w Polsce Ludowej. Pal. 1977, nr 1, s. 51 i cytowana tam literatura francusko- oraz rosyjskojęzyczna. 
Jej początki sięgają z jednej strony kojarzonego z osobami F. Gramatica (1901-1979) i M. Ancela (1902-1990) kryminalno-politycznego kierunku „obrony społecznej”, którego przedstawiciele co do zasady programowo odrzucali klasyczne pojęcia kary kryminalnej i prawa karnego, postulując uczynienie centralnym punktem procesu karnego nie czyn, ale sprawcę i jego osobowość ${ }^{2}$, a z drugiej dostrzeganej wówczas ogólnej fascynacji działalnością sądów przysięgłych znanych z państw common law, gdzie wydawany przez ławę przysięgłych werdykt dotyczący winy był w sposób wyraźny oddzielony w czasie od orzekania przez zawodowego sędziego o karnoprawnych konsekwencjach przypisanego oskarżonemu czynu ${ }^{3}$.

W polskim piśmiennictwie karnoprocesowym jak dotąd najgłębszą analizę doktrynalną omawianego konceptu, jeszcze w latach sześćdziesiątych ubiegłego wieku, zaprezentował M. Cieślak, który postawił sobie zadanie znalezienia odpowiedzi m.in. na następujące pytania:

1) czy i jakie korzyści mogą wynikać z przyjęcia konstrukcji dwufazowego procesu karnego i jakie są jej ewentualne wady?,

2) czy i w jakim zakresie konstrukcja ta dałaby się pogodzić z przepisami prawnymi obowiązującymi w Polsce i czy w ich świetle nie znajduje ona częściowego zastosowania również obecnie? ${ }^{4}$.

Od chwili ukazania się przywołanej wyżej pracy zainteresowanie tą „modną” - jak nazywał ją sam M. Cieślak - koncepcją stopniowo wygasało. Już w latach siedemdziesiątych XX w. wydawało się przesądzone, że stanowiąca wytwór „burżuazyjnej nauki prawa” idea nie przystaje do ogólnych założeń socjalistycznej nauki procesu karnego, chociaż uważam, że na jej kategoryczne odrzucenie (zbyt) duży wpływ miało podejście do oceny tegoż konceptu od strony „materialnoprawnej”. Kontestujący pomysł dwufazowego procesu nie potrafili w dostatecznym stopniu oddzielić go od samej doktryny ruchu obrony społecznej (i leżącej u jej podstaw szczególnoprewencyjnej wizji prawa karnego), z założenia sprzecznej z koncepcją państwa socjalistycznego ${ }^{5}$, przez co nie podejmowali próby dostosowania teoretycznego szkieletu tej idei do modelu prawa karnego opartego w głównej mierze na represyjnej funkcji kary m.in. poprzez rezygnację z najbardziej skrajnych jej elementów, takich jak powierzenie orzekania w przedmiocie sankcji karnej różnego rodzaju specjalistom po-

2 J. WARYLEWSKI: Kierunki i szkoły $w$ nauce prawa karnego. W: System Prawa Karnego. T. I. Zagadnienia ogólne. Red. A. МаRеK. Warszawa 2010, s. 81-84; J. SAWICKI: O nowej ochronie społecznej. PiP 1955, z. 1, s. 18 i nast.

${ }^{3}$ R. VouIn: La division du procès pénal en deux phases. W: L'individualisation des mesures prises à l'égard du délinquant. Paryż 1954, s. 172.

${ }^{4}$ M. CIEślaK: Koncepcja podziału procesu karnego na dwie fazy (jej miejsce i perspektywy w prawie karnym). PiP 1968, z. 3, s. 389.

5 A. Murzynowski: Refleksje na temat nauki..., s. 52. 
zbawionym przygotowania prawniczego (np. psychologom lub psychiatrom), zupełna rezygnacja z elementów kontradyktoryjności czy wreszcie niemal absolutny brak jawności (zarówno zewnętrznej, jak i wewnętrznej) drugiej fazy procesu.

Tytułowa koncepcja nie zaskarbiła sobie sympatii również ze strony prawodawcy, który nie poświęcił jej uwagi w toku prac nad kodyfikacją karną z 1969 r. czy przy okazji uchwalania obecnie obowiązującej ustawy procesowej z 1997 r., ani wreszcie w związku z wprowadzaniem w życie obszerniejszych zmian w procedurze karnej (mam tu na myśli zwłaszcza fundamentalne reformy przeprowadzone w latach 2013 i 2015).

$\mathrm{Na}$ gruncie aktualnie obowiązującej kodyfikacji idea dwufazowego procesu karnego była jak dotąd poruszana zupełnie sporadycznie, w dodatku jedynie na uboczu rozważań na główny (tj. inny) temat. Przykładowo w 2011 r. bezpośrednio nawiązał do niej S. Steinborn, uznając, że argumenty wysuwane przed laty na rzecz podziału postępowania przed sądem I instancji na dwa etapy - przynajmniej prima facie - w dużym stopniu mogłyby posłużyć również do uzasadnienia szeroko omawianej przez tego Autora konstrukcji horyzontalnej prawomocności części wyroku $^{6}$. Chodzi tu np. o sytuacje, w których - na skutek uchylenia przez sąd odwoławczy kontrolowanego orzeczenia jedynie w części - sąd rozpoznający sprawę $\mathrm{w}$ postępowaniu ponownym $\mathrm{w}$ I instancji rozstrzyga co do zasady (z zastrzeżeniem art. $442 \S 1$ zd. 2 Kodeksu postępowania karnego ${ }^{7}$ ) wyłącznie o karze i innych środkach reakcji karnej.

$\mathrm{Z}$ kolei wprost postulat rozdzielenia postępowania głównego na etap związany z ustalaniem winy oskarżonego i etap, w którym sąd badałby wyłącznie okoliczności mające wpływ na wymiar kary i innych środków, w ostatnim czasie wyraził M. Wantoła. Zasadność wdrożenia w życie omawianego rozwiązania uznał on za jeden z opisanych przez siebie skutków odmienności dotyczących ciężaru dowodu i obowiązku dowodzenia w zakresie rozstrzygania o zastosowaniu różnorakich środków reakcji karnej względem ogólnych reguł rządzących dowodzeniem winy ${ }^{8}$.

Celem tej pracy jest znalezienie odpowiedzi na pytanie o atrakcyjność koncepcji podziału procesu na dwie fazy po upływie ponad pół wieku od jej ostatniej szerszej analizy, w tym zwłaszcza o ewentualne praktyczne korzyści płynące z zaimplementowania tej konstrukcji do rodzimego

6 S. SteInborn: Prawomocność części orzeczenia w procesie karnym. Warszawa 2011, s. $145-146$.

7 Ustawa z dnia 6 czerwca 1997 r. - Kodeks postępowania karnego, Dz.U. 2020, poz. 30 .

${ }^{8}$ M. WantoŁa: Ciężar dowodu i obowiqzek dowodzenia okoliczności wptywajacych na wymiar kary i innych środków reakcji karnej. CPKNP 2019, poz. 9 (wyd. elektroniczne), s. 27-29. 
porządku prawnego, jak również - w przypadku udzielenia pozytywnej odpowiedzi na pierwsze z pytań - rozwiązanie niektórych szczegółowych problemów z tym związanych. Punktem wyjścia dla dalszych rozważań będzie spojrzenie na ideę dwufazowego procesu karnego jako na konstrukcję o charakterze czysto procesowym, a zatem odrzucenie jej funkcjonalnego związku z jakimkolwiek modelem materialnego prawa karnego i uznanie, że - bez względu na ocenę jej przydatności dla praktyki wymiaru sprawiedliwości - w porównywalnym stopniu „pasuje” ona do wszystkich wiodących obecnie koncepcji kary kryminalnej.

Przyjmując za trafną perspektywę badawczą zaproponowaną niegdyś przez M. Cieślaka, w pierwszej kolejności zaprezentowane zostaną niektóre z argumentów wysuwanych przez zwolenników, jak również przeciwników tytułowej koncepcji. Następnie skupię się na poszukiwaniu jej zrębów wśród obecnie funkcjonujących rozwiązań karnoprocesowych. Przedmiotem dalszej analizy stanie się odpowiedź na bez wątpienia najważniejsze pytanie, tj. czy i ewentualnie w jakim kształcie mechanizm podziału postępowania jurysdykcyjnego powinien stać się elementem polskiego procesu karnego, w związku z czym końcowa część artykułu przybierze postać wniosków de lege ferenda.

\section{Argumenty za i przeciwko podziałowi procesu karnego na dwie fazy}

Zwolennicy przedmiotowego rozwiązania najczęściej wskazują na niecelowość badania oskarżonego przed stwierdzeniem winy, jeżeli miałby on później zostać uniewinniony z powodu braku podstaw do przypisania mu odpowiedzialności karnej za zarzucony czyn ${ }^{9}$. Z kolei jego przeciwnicy zauważają, że większość danych prima facie mających dotyczyć wyłącznie osoby sprawcy w rzeczywistości w równym stopniu odnosi się także do jego czynu. Chodzi tu m.in. o badanie znamion strony podmiotowej przestępstwa (np. tego, czy sprawca to czy owo mógł albo powinien był przewidzieć lub czy popełnił zarzucony mu czyn pod wpływem silnego wzburzenia albo współczucia) i kwestii zawinienia (np. poczytalności oskarżonego czy jego przekonania, że zachodzi okoliczność wyłączająca bezprawność albo winę ${ }^{10}$. Nie bez racji od lat wskazuje się, że „Ustalenie winy, a zatem ustalenie, czy sprawca nie działał w błędzie, czy w chwili czynu był poczytalny, czy przymus w konkretnym wypadku był nieod-

${ }^{9}$ M. Rolland: La scission du procès en deux phases. W: L'individualisation des mesures prises à l'égard du délinquant. Paryż 1954, s. 140-141. Cyt. za: M. CIEŚLAK: Koncepcja podziatu procesu..., s. 389.

${ }^{10}$ M. CIEŚLAK: Koncepcja podziału procesu..., s. 391. 
porny, a przede wszystkim, gdy chodzi o przestępstwa nieumyślne, czy następstwa swego zachowania się mógł przewidzieć - to są momenty, dla których ustalenia wszelkie wiadomości o przestępcy i przestępcach są po prostu nieodzowne" ${ }^{11}$. Co więcej, pewne właściwości oskarżonego w niektórych przypadkach mogą mieć także znaczenie dowodowe w odniesieniu do kwestii popełnienia przez niego zarzuconego mu czynu, ponieważ dokładne poznanie badanego przestępcy może nieraz, w konfrontacji ze sposobem popełnienia danego przestępstwa, dostarczyć ważnej poszlaki mogącej potwierdzić albo zaprzeczyć tezie o popełnieniu tego przestępstwa przez konkretnego oskarżonego ${ }^{12}$.

Podnosi się również, że przeznaczenie specjalnej fazy postępowania głównego wyłącznie na badanie osobowości oskarżonego pod kątem widzenia wyboru najodpowiedniejszego środka reakcji karnej niewątpliwie przyczyniłoby się do koncentracji uwagi sądu na osobie oskarżonego, którego w modelu ,prawa karnego czynu” nie bada się tak szczegółowo jak zachowania, którego miał się on dopuścić ${ }^{13}$. W wielu przypadkach to nie kwestia winy oskarżonego będzie budzić wątpliwości, ale wyłącznie rodzaj reakcji karnej, jaka powinna być wobec niego zastosowana. Co więcej, dla samego sprawcy przestępstwa największe znaczenie ma często nie samo ustalenie, że je popełnił, ale to, jaka kara zostanie mu za nie wymierzona, ewentualnie - czy będzie mógł skorzystać z dobrodziejstwa instytucji warunkowego umorzenia postępowania ${ }^{14}$. Z drugiej zaś strony trafnie zauważono, że nie sposób badać właściwości oskarżonego w oderwaniu od jego czynu. Wszak czyn jest w istocie ,symptomem pewnych cech osobowości oskarżonego, jego charakteru, skłonności, trybu życia itp." ${ }^{15}$. Siłę argumentu dotyczącego sztuczności podziału procesu na część poświęconą winie i część poświęconą karze w sposób szczególnie wyraźny widać na przykładzie badania stopnia społecznej szkodliwości, który z jednej strony decyduje o możliwości przypisania oskarżonemu odpowiedzialności za popełniony czyn (art. $1 \S 2$ k.k. ${ }^{16}$ ), a z drugiej wpływa również na

11 I. ANDREJEW: Ustawowe znamiona przestępstwa. Warszawa 1959, s. 181.

12 Szerzej M. CieślaK: Koncepcja podziału procesu..., s. 392 i podane tam przykłady.

${ }^{13}$ Ibidem, s. 390; por. A. MuRZYNowsKI: Refleksje na temat nauki..., s. 51.

14 Tak słusznie M. WANToŁA: Ciężar dowodu i obowiązek..., s. 4. Autor ten wskazuje, że z tym ostatnim przypadkiem możemy mieć do czynienia zwłaszcza wtedy, gdy okoliczności sprawy nie budzą wątpliwości, sam oskarżony przyznaje się do winy, a dodatkowo do wykonywania przez niego dotychczasowego zawodu nie jest konieczny status osoby niekaranej; por. M. WAIBLINGER: Der rechtliche Charakter und die Bedeutung der Schuldigerklärung im Strafprozeß. Das Problem der Teilrechtskraft. W: Strafprozess und Rechtsstaat. Festschrift zum 70. Geburtstag von Prof. Dr. H.F. Pfenninger. Zurych 1956, s. 167, którego zdaniem orzeczenie skazujące niejednokrotnie jest dla sprawcy większą dolegliwością niż sama kara.

${ }_{15}$ M. CIEśLAK: Koncepcja podziatu procesu..., s. 391.

16 Ustawa z dnia 6 czerwca 1997 r. - Kodeks karny, Dz.U. 2019, poz. 1950 i 2128. 
wymiar orzeczonej przez sąd kary (art. 53 \$1 k.k.), w związku z czym okoliczność ta musiałby być badana dwukrotnie, co w konsekwencji prowadziłoby do bezzasadnego przedłużenia postępowania jurysdykcyjnego. Podobnie przedstawia się kwestia zawinienia (por. art. 1 \$ oraz art. 53 $\S 1$ k.k.). Innymi słowy, ta sama okoliczność - korzystna dla sprawcy jako obniżająca stopień społecznej szkodliwości lub zawinienia - raz może stanowić o braku podstaw do przypisania mu odpowiedzialności karnej, a innym razem będzie wpływać jedynie na niższy wymiar kary ${ }^{17}$.

Współcześnie za najważniejszy argument przemawiający za przyjęciem koncepcji dwufazowego procesu karnego uznaje się okoliczność, zgodnie z którą dowodzenie przez oskarżonego (lub jego obrońcę) faktów niezwiązanych bezpośrednio z okolicznościami czynu, ale mogących mieć wpływ na wysokość wymierzonej mu kary i innych środków reakcji karnej - teoretycznie korzystnych z jego perspektywy - opiera się na milczącym założeniu o spełnieniu przesłanek przypisania mu odpowiedzialności karnej za dane przestępstwo, a zatem stanowi swoiste przyznanie się do jego popełnienia ${ }^{18}$. O realności takiej obawy może świadczyć również praktyka interpretowania w postępowaniu apelacyjnym tzw. zarzutów ewentualnych (alternatywnych), formułowanych przez skarżącego na wypadek nieuwzględnienia zarzutów głównych ${ }^{19}$. Postawienie w apelacji wniesionej na korzyść oskarżonego, obok zarzutu głównego, dotyczącego np. błędu w ustaleniach faktycznych przyjętych za podstawę wyroku, również ewentualnego zarzutu rażącej niewspółmierności kary, częstokroć traktowane jest jako sugerowanie sądowi odwoławczemu istnienia wątpliwości co do zasadności zarzutu głównego, przez co nierzadko prowadzi do jego bezskuteczności.

Oznacza to, że w modelu jednofazowego postępowania głównego oskarżony jedynie formalnie ma zagwarantowaną pełną swobodę w za-

17 Podobnie M. Wantoła: Ciężar dowodu i obowiązek..., s. 17. Zob. również rozważania W. Wróbla, który wskazuje, że w praktyce okoliczność wpływająca na podwyższenie stopnia społecznej szkodliwości czynu lub stopnia zawinienia rozpatrywana będzie wyłącznie na płaszczyźnie wymiaru kary, z uwagi na funkcjonowanie domniemania, zgodnie z którym stwierdzenie realizacji znamion czynu zabronionego oznacza, że stopień społecznej szkodliwości był wyższy niż znikomy, a sprawcy można przypisać winę w czasie czynu - W. WróbeL: O domniemaniach w zakresie przesłanek odpowiedzialności karnej. „Zeszyty Naukowe Uniwersytetu Jagiellońskiego" 2006, nr 5, s. 247 i nast.

${ }_{18}$ Tak trafnie M. WANTOŁA: Ciężar dowodu i obowiq̨zek..., s. 26-27, który za przykład podaje dowodzenie okoliczności przyczynienia się przez pokrzywdzonego do powstania szkody czy też okoliczność jej częściowego naprawienia przez oskarżonego; por. M. KLEJNOWSKA: Wyjątki od regut rozkładu ciężaru dowodu w procesie karnym. „Ius et administratio" 2004, z. 1, s. 51.

19 Szerzej D. ŚwIEcKi: Konstrukcja apelacji jako środka odwoławczego w procesie karnym. Warszawa 2018, s. 87. 
kresie dowodzenia okoliczności mających wpływ wyłącznie na wymiar kary, podczas gdy $\mathrm{w}$ rzeczywistości - z przyczyn immanentnie związanych ze skutecznością taktyki obrony - zmuszony jest skoncentrować się albo na kwestii winy, albo na kwestii kary. Skoro bowiem obrońca podnosi szereg argumentów przemawiających za niemożliwością przypisania oskarżonemu jakiejkolwiek odpowiedzialności karnej, to jasne jest, że dla zachowania spójności przyjętej linii obrony i przekonania organu procesowego o oczywistości przedstawianej przez siebie wersji wydarzeń nie będzie wdawał się w spór na temat okoliczności niemających żadnego znaczenia $\mathrm{w}$ razie udowodnienia, że przestępstwa w ogóle nie popełniono albo też że nie popełnił go oskarżony. Bez wątpienia wpływa to na ograniczenie przysługującego oskarżonemu prawa do obrony w jego aspekcie materialnym, rozumianego jako zespół uprawnień procesowych pozwalających dokonywać czynności zmierzających zarówno do odparcia oskarżenia, jak i do samego złagodzenia odpowiedzialności ${ }^{20}$.

$\mathrm{Z}$ uwagi na zaproponowaną $\mathrm{w}$ dalszej części pracy zmianę kryterium podziału poszczególnych faz z tego, które stanowiło podstawę do wysunięcia wszystkich wskazanych wyżej argumentów, zasadzającego się na prostym przeciwstawieniu okolicznościom istotnym dla kwestii winy okoliczności mających znaczenie wyłącznie dla kwestii kary, ich szczegółową ocenę uznaję w tym miejscu za w zupełności zbędną, odsyłając w tym zakresie do przywołanej wcześniej literatury przedmiotu.

\section{Elementy koncepcji dwufazowego procesu karnego - uwagi de lege lata}

Niekiedy przy analizie tytułowej problematyki, zwykle dla wykazania, że założenia koncepcji podziału procesu na dwie fazy ze swej istoty nie są aż tak odległe od obowiązującego modelu postępowania jurysdykcyjnego, próbuje się odszukać jej elementów w aktualnym stanie prawnym. Wskazuje się, że z podobną sytuacją mamy do czynienia w przypadkach, w których rozstrzygnięcie o zastosowaniu danego środka zasadniczo powinno być zamieszczone $\mathrm{w}$ wyroku, jednakże ustawodawca dopuszcza możliwość ich orzeczenia również $\mathrm{w}$ drodze odrębnego postanowienia, którego wydanie częstokroć będzie wymagało przeprowadzenia dodatkowego postępowania dowodowego. Przykładowo, w myśl art. 420 § 1 k.p.k., sąd może uzupełnić wyrok m.in. o rozstrzygnięcie w przedmiocie prze$\mathrm{padku}^{21}$. Zasadnicza różnica pomiędzy obydwoma mechanizmami polega

20 J. SkorupKa. W: Proces karny. Red. J. SKorupKa. Wyd. 2. Warszawa 2018, s. 209.

${ }^{21}$ Por. M. CIEŚLAK: Koncepcja podziatu procesu..., s. 395; M. WantoŁa: Ciężar dowodu i obowiazek..., s. 29. 
jednak na tym, że instytucja uzupełnienia wyroku została przewidziana raczej jako próba naprawienia oczywistych błędów powstałych na skutek przeoczenia ze strony sądu orzekającego w pozostałym zakresie ${ }^{22}$, podczas gdy w modelu dwufazowego procesu karnego podział wyroku na dwie części byłby sytuacją zwyczajną, tj. z góry założoną już w momencie orzekania o winie.

Omawiane rozwiązanie wykazuje również znaczące podobieństwo do przywołanego już wcześniej zagadnienia prawomocności horyzontalnej, która ma miejsce wówczas, gdy w postępowaniu przeciwko jednemu oskarżonemu, dotyczącym jednego czynu, wyrok uprawomocni się wyłącznie co do kwestii, która nie mogłaby stanowić samodzielnego przedmiotu postępowania, czego klasycznym przykładem jest sytuacja, gdy wyrok jest prawomocny w zakresie rozstrzygnięcia o winie, a przedmiotem dalszego postępowania jest jedynie kwestia kary i środków karnych $^{23}$. W ramach obu konstrukcji dochodzi do oddzielenia w czasie orzekania o winie i karze, z tym że - podobnie jak w przypadku postanowienia uzupełniającego - również horyzontalna prawomocność części orzeczenia jawi się jako coś niestandardowego (niezaplanowanego), wynikającego wyłącznie ze specyfiki danego układu procesowego, w którym wyrok został zaskarżony jedynie w części dotyczącej kary (art. $425 \$ 2$ zd. 1 k.p.k.) albo wprawdzie został zaskarżony w szerszym zakresie, ale sąd odwoławczy uchylił go i przekazał sądowi I instancji do ponownego rozpoznania wyłącznie w części dotyczącej kary (art. 437 § 1 in fine k.p.k.). Jedynie na marginesie warto zauważyć, że z uwagi na niedawne uchylenie za sprawą Ustawy z dnia 19 lipca 2019 r. o zmianie ustawy - Kodeks postępowania karnego oraz niektórych innych ustaw ${ }^{24}$ wyrażonej w art. 454 $\S 3$ k.p.k. reguły ne peius, zakazującej sądowi odwoławczemu zaostrzenia kary poprzez wymierzenie oskarżonemu kary dożywotniego pozbawienia wolności, ostatnia ze wskazanych sytuacji powinna obecnie należeć do niezwykle rzadkich. Pozostałe przypadki spełnienia przesłanek pozwala-

${ }^{22}$ P. HofmaŃski, E. SADZIK, K. ZgryzeK. W: Kodeks postępowania karnego. T. II. Komentarz do artykułów 297-467. Red. P. HofMAŃsKi. Wyd. 4. Warszawa 2011, s. 681; zob. również post. SA w Lublinie z dnia 17 listopada 2010 r., II AKz 485/10. LEX nr 785264, w którym możliwość orzeczenia przepadku w trybie art. 420 \$1 k.p.k. ograniczono wyłącznie do przypadków, gdy orzeczenie tego środka było w konkretnym stanie faktycznym obligatoryjne; odmiennie A. WAŻNY. W: Kodeks postępowania karnego. Komentarz. Red. A. SAKowicz. Wyd. 8. Warszawa 2018, s. 1025, którego zdaniem sąd może świadomie zaniechać rozstrzygnięcia kwestii przepadku przedmiotów również „z uwagi na złożoność problemu".

23 Zob. S. Steinborn: Prawomocność części orzeczenia..., s. 112 i cytowana tam literatura niemieckojęzyczna; wyr. SA w Warszawie z dnia 13 marca 2003 r., II AKa 87/03. OSA 2003, nr 12, poz. 119.

${ }^{24}$ Dz.U. poz. 1694. 
jących na uchylenie wyroku wyłącznie w zakresie kary należą do absolutnie wyjątkowych (orzeczenie kary lub innego środka nieznanych ustawie, o których mowa w art. $439 \S 1$ pkt 5 k.p.k.), albo też - jak w wypadku stwierdzenia konieczności przeprowadzenia na nowo przewodu w całości - nie sposób wyobrazić sobie sytuacji, w której zaistnienie tej przesłanki nie poskutkuje uchyleniem wyroku również w części dotyczącej winy.

Śladów komentowanej koncepcji można się doszukać również w art. 436 k.p.k., który zezwala sądowi II instancji na ograniczenie rozpoznania środka odwoławczego tylko do poszczególnych uchybień podniesionych w jego treści, jeżeli rozpoznanie w tym zakresie jest wystarczające do wydania orzeczenia, a analizowanie pozostałych uchybień byłoby przedwczesne lub bezprzedmiotowe dla dalszego toku postępowania. W przypadku skorzystania z tego mechanizmu sąd odwoławczy przystąpi do badania wyłącznie uchybień najdalej idących, ponieważ - w razie ich stwierdzenia - wszelkie inne i tak nie będą miały żadnego wpływu na ostateczny wynik postępowania. Dopiero w razie ich niestwierdzenia zobowiązany będzie zająć się również kwestią pozostałych uchybień. Podobnie w modelu dwufazowego postępowania jurysdykcyjnego sąd ogranicza rozpoznanie sprawy na pierwszym etapie wyłącznie do kwestii winy, jako że stwierdzenie jej braku uczyni bezprzedmiotowym badanie okoliczności mających znaczenie dla wymiaru kary. Jedynie w razie stwierdzenia, że oskarżony rzeczywiście powinien ponieść odpowiedzialność za przypisany mu czyn zabroniony, na drugim etapie przystąpi do poszukiwania najtrafniejszego środka reakcji karnej.

Z kolei M. Wantoła dostrzega pewne podobieństwa pomiędzy koncepcją podziału procesu karnego na dwie fazy a postępowaniem w przedmiocie odpowiedzialności podmiotów zbiorowych ${ }^{25}$. Wprawdzie ten szczególny rodzaj postępowania karnego sensu largo bynajmniej nie ogranicza się wyłącznie do kwestii kary, tym niemniej analiza przesłanek odpowiedzialności takiego podmiotu dowodzi, że de lege lata warunkiem jej badania (faza druga) jest uprzednie prawomocne stwierdzenie $\mathrm{w}$ innym postępowaniu faktu popełnienia przestępstwa lub przestępstwa skarbowego przez osobę działającą w imieniu lub w interesie podmiotu zbiorowego bądź też z nim współdziałającą (faza pierwsza) ${ }^{26}$. Należy zauważyć, że podobieństwo to ma najprawdopodobniej jedynie charakter czasowy, ponieważ w myśl projektowanych obecnie rozwiązań w zakresie odpowiedzialności podmiotów zbiorowych ma być ona w pełni nie-

${ }_{25}$ M. WANTOŁA: Ciężar dowodu i obowiązek..., s. 28-29.

${ }^{26}$ Zob. art. 3-5 Ustawy z dnia 28 października 2002 r. o odpowiedzialności podmiotów zbiorowych za czyny zabronione pod groźbą kary, Dz.U. 2019, poz. 628 i 1214. 
akcesoryjna, tzn. niezależna od odpowiedzialności tzw. bezpośredniego sprawcy $^{27}$.

Omawiana koncepcja ma swój odpowiednik także na gruncie postępowania cywilnego. Jest nim unormowany w art. 318 Kodeksu postępowania cywilnego ${ }^{28}$ wyrok wstępny, w którego treści uwzględnia się roszczenie co do samej zasady („czy się należy”). W przypadku jego wydania sąd może zarządzić dalszą rozprawę w celu ustalenia wysokości tego roszczenia (,ile się należy” ${ }^{29}$. Instytucja ta opiera się na założeniu, że sąd powinien ustosunkować się do żądania w sposób całościowy - pozytywny lub negatywny, co jednak samo przez się nie oznacza jeszcze, że musi to uczynić w jednym orzeczeniu ${ }^{30}$. Wydaje się, że pomimo licznych różnic pomiędzy obiema procedurami również na gruncie procesu karnego najistotniejsze jest, ażeby sąd przesądził kwestię stanowiącą jego główny przedmiot w sposób ostateczny, choćby nawet miało się to odbywać stopniowo.

Równocześnie uważam, że dostrzeżone podobieństwo obu konstrukcji uzasadnia przejęcie na grunt analizowanego mechanizmu siatki pojęciowej wypracowanej w nauce postępowania cywilnego, w związku z czym dla uproszczenia, aby uniknąć konieczności wielokrotnego powtarzania w sposób opisowy, o którym z orzeczeń mowa - w dalszych rozważaniach na określenie wyroku wydawanego w pierwszej fazie będę zamiennie używał technicznoprawnego terminu „wyrok wstępny”, zaś na oznaczenie wyroku wydawanego w drugiej fazie - wyrażenia ,wyrok końcowy”31.

\section{Kryterium podziału poszczególnych faz postępowania}

Jak zasygnalizowano już wcześniej, przyjmowane przez większość przedstawicieli polskiej (choć nie tylko) doktryny prawa karnego proce-

${ }^{27}$ Por. art. 7 rządowego projektu ustawy o odpowiedzialności podmiotów zbiorowych za czyny zabronione pod groźbą kary. Źródło: http://orka.sejm.gov.pl/Druki8ka.nsf/ Projekty/8-020-1211-2019/\$file/8-020-1211-2019.pdf [dostęp: 26.02.2020].

${ }^{28}$ Ustawa z dnia 17 listopada 1964 r. - Kodeks postępowania cywilnego, Dz.U. 2019, poz. 1460 ze zm.

29 A. Góra-BŁaszczyKowsKa. W: Kodeks postępowania cywilnego. T. IA. Komentarz. Art. 1-42412. Red. A. Góra-BŁaszczyKowsKa. Wyd. 3. Warszawa 2020, s. 945; por. M. CieślaK: Koncepcja podziatu procesu..., s. 397-398; M. WantoŁA: Ciężar dowodu i obowiazek..., s. 29.

${ }^{30}$ K. Markiewicz. W: Kodeks postępowania cywilnego. T. I. Komentarz. Art. 1-366. Red. A. MarciniaK, K. PiaseCKI. Wyd. 7. Warszawa 2016, s. 1376.

31 Określenia „wyrok końcowy” na gruncie postępowania cywilnego używają m.in. W. Berutowicz: Postępowanie cywilne w zarysie. Wyd. 3. Warszawa 1984, s. 341 oraz J. Gudowski. W: Kodeks postępowania cywilnego. Komentarz. T. II. Postępowanie rozpoznawcze. Red. T. Ereciński. Wyd. 5. Warszawa 2016, s. 497. 
sowego kryterium podziału procesu karnego na dwie fazy, opierające się na rozdzieleniu kwestii winy od kwestii kary, można zastąpić innym, które $\mathrm{z}$ jednej strony zachowa atrakcyjność argumentów przemawiających za wprowadzeniem w życie tytułowej koncepcji, a z drugiej wyeliminuje uciążliwości związane co najmniej z częścią jej wadliwości. Podobnie jak ocena samej konstrukcji dwufazowego procesu karnego, tak również patrzenie na kryterium jego ewentualnego podziału zbyt mocno zakorzenione jest $\mathrm{w}$ myśleniu opartym na rozwiązaniach prawa karnego materialnego, w którym za oczywiste i naturalne uznaje się przeciwstawianie sobie zagadnień związanych ze sprawstwem i winą (nauka o przestępstwie) problematyce reakcji państwa na stwierdzone przestępstwo (nauka o karze), co znajduje swoje odbicie nie tylko w bodaj wszystkich aktualnie wydawanych podręcznikach z zakresu prawa karnego ${ }^{32}$, ale również w strukturze samej ustawy karnej. Tymczasem przy analizie rozwiązań proceduralnych (istniejących lub nawet dopiero postulowanych) ten klasyczny materialnoprawny podział może - z różnych zresztą względów nie być tak atrakcyjny jak inny, in concreto w sposób pełniejszy oddający specyfikę procesu karnego, w tym zwłaszcza problemy związane z dowodowym ustalaniem okoliczności istotnych z punktu widzenia instytucji prawa materialnego.

Pomysłodawcą przeprowadzenia cezury pomiędzy fazami postępowania głównego w sposób odmienny od typowego był francuski prawnik R. Vouin (1913-1975), którego zdaniem faza pierwsza powinna się kończyć orzeczeniem przesądzającym wyłącznie kwestię popełnienia przez oskarżonego zarzuconego mu czynu, zaś faza druga obejmowałaby wszystkie pozostałe zagadnienia, a więc rozstrzygnięcie kwestii poczytalności oskarżonego i jego odpowiedzialności za przypisany mu czyn oraz określenie prawnych konsekwencji tego czynu ${ }^{33}$. Doszłoby zatem do przesunięcia części kwestii rozpatrywanych - przy zastosowaniu klasycznego kryterium podziału - w fazie pierwszej do fazy drugiej, a przez to zdezaktualizowałby się również zastany sposób nomenklatury stosowany na oznaczenie poszczególnych faz postępowania głównego, skoro faza pierwsza stałaby się etapem orzekania zaledwie o „części winy”, a faza druga etapem orzekania i o winie, i o karze. Jak pisał M. Cieślak: „Modyfikacja

32 Zob. spisy treści m.in. w następujących podręcznikach akademickich: W. WróBeL, A. Zoll: Polskie prawo karne. Część ogólna. Kraków 2013; M. BojaRski. Red. Prawo karne materialne. Część ogólna i szczególna. Wyd. 7. Warszawa 2017; L. Gardocki: Prawo karne. Wyd. 21. Warszawa 2019.

33 R. Vouin: La division du procès pénal en deux phases. W: L'individualisation..., s. 175 i nast.; aprobująco M. CIEŚLAK: Koncepcja podziału procesu..., s. 398; odmiennie M. WANTOŁA: Ciężar dowodu i obowiązek..., s. 27 i nast., który postuluje wyodrębnienie fazy, w której badano by wyłącznie okoliczności wpływające na wymiar środków reakcji karnej. 
ta nie tylko zredukowałaby nieco ujemne skutki sztucznego rozdziału między »badaniem czynu « a »badaniem sprawcy «, ale także usunęłaby ten oczywisty absurd, jakim byłoby (w myśl koncepcji pierwszej [tj. opartej na podziale na okoliczności związane z winą i okoliczności związane z karą - B.Ł.]) oderwanie badań psychiatrycznych, niezbędnych przecież dla oceny poczytalności oskarżonego, od pozostałych badań jego osobowości, a zwłaszcza ekspertyzy psychologicznej. Takie ujęcie koncepcji podziału procesu miałoby nadto i tę wartość, że pozwoliłoby konsekwentnie przeprowadzić zasadę, zgodnie z którą faza druga może istnieć tylko $\mathrm{w}$ razie przypisania oskarżonemu zarzuconego mu czynu (nulla poena sine crimine), a negatywne zakończenie fazy pierwszej kończy proces w sposób definitywny w każdym wypadku - a więc także wtedy, gdy oskarżony jest niepoczytalny" 34 .

Przyjęcie koncepcji rozdzielenia procesu karnego na etap dotyczący sprawstwa i etap poświęcony wszystkim innym zagadnieniom pozwoliłoby z jednej strony na wykorzystanie wszystkich wskazanych wyżej zalet samej idei dwufazowego postępowania głównego, a z drugiej na uniknięcie przynajmniej części wad przeprowadzenia podziału według klasycznego wzorca (wina i kara). Z jednej strony - inaczej niż w modelu jednofazowym - sąd nie badałby okoliczności istotnych jedynie dla wymiaru kary niejako na zapas (tj. na wypadek skazania), a z drugiej - inaczej niż w klasycznym modelu dwufazowym - nie dochodziłoby do dwukrotnego badania np. winy (w znaczeniu materialnoprawnym) czy stopnia społecznej szkodliwości, które wszak, jak już była o tym mowa, stanowią okoliczności mające istotne znaczenie zarówno dla winy (w znaczeniu procesowym), jak i dla kary. Oznaczałoby to, że wbrew pozorom przeciwko wprowadzeniu w życie komentowanego mechanizmu nie przemawia również wzgląd na ekonomikę postępowania ${ }^{35}$, albowiem jego przemyślane uregulowanie i korzystanie $\mathrm{z}$ niego mogłoby wręcz skrócić całkowity czas trwania konkretnych procesów karnych.

$\mathrm{Z}$ jednej strony - inaczej niż w modelu jednofazowym - sąd mógłby skoncentrować się na osobie oskarżonego, a z drugiej - inaczej niż w klasycznym modelu dwufazowym - nie rozstrzygałby kwestii kary w oderwaniu od czynników takich jak wina czy społeczna szkodliwość czynu, których z kolei nie ma potrzeby badać w celu udzielenia odpowiedzi na pytanie o to, czy oskarżony zrealizował znamiona zarzuconego mu przestępstwa. Na pierwszy rzut oka pewne wątpliwości może budzić fakt, że znamiona strony podmiotowej typu czynu zabronionego są przecież ściśle związane z osobą oskarżonego, przez co w zakresie ich badania obie fazy

\footnotetext{
${ }^{34}$ M. CIEŚLAK: Koncepcja podziatu procesu..., s. 398.

35 Tak M. WantoŁa: Ciężar dowodu i obowiązek..., s. 28.
} 
mogłyby niejako „zlać się” ze sobą. W rzeczywistości jednak, z uwagi na oczywistą niemożliwość wniknięcia w głąb umysłu oskarżonego, okoliczności takie jak działanie w celu osiągnięcia korzyści majątkowej czy też w celu przywłaszczenia w praktyce ustalane są głównie (a niekiedy nawet wyłącznie) na podstawie okoliczności przedmiotowych związanych z konkretnym zdarzeniem, w oparciu o sam sposób działania ${ }^{36}$.

Opisywana formuła, inaczej aniżeli przeznaczenie jednej $\mathrm{z}$ faz wyłącznie kwestii kary, hołdowałaby przy tym wyróżnianej w niemieckim procesie karnym zasadzie, zgodnie z którą wymiar kary może być jedynie wynikiem merytorycznego postępowania co do istoty sprawy (das tatrichterliche Verfahren). W piśmiennictwie wyrażono wprawdzie pogląd o jej nieobowiązywaniu w polskim procesie karnym, tym niemniej warto zwrócić uwagę, że sformułowano go jeszcze na gruncie poprzedniego modelu postępowania apelacyjnego, w którym zasadą było wymierzanie przez sąd II instancji kary pomimo przysługiwania mu ograniczonych możliwości czynienia własnych ustaleń faktycznych ${ }^{37}$.

Wreszcie poświęcenie pierwszej fazy postępowania jurysdykcyjnego wyłącznie kwestii sprawstwa pozwoliłoby oskarżonemu skupić się na dowodzeniu, że to nie on jest sprawcą zarzuconego mu czynu albo że opisane w akcie oskarżenia zdarzenie historyczne nie miało nigdy miejsca. Równocześnie miałby on gwarancję, że w razie niepowodzenia tej akcji procesowej w dalszym toku sprawy będzie miał możliwość skupienia uwagi sądu np. na znikomości społecznej szkodliwości czynu zaistnieniu okoliczności wyłączającej winę, ograniczonej poczytalności czy pojednaniu się z pokrzywdzonym, bez obaw o potraktowanie tego typu argumentacji za przejaw konkludentnego przyznania się do popełnienia przestępstwa.

Zdaniem M. Cieślaka przyjęcie wskazanego wyżej kryterium podziału poszczególnych faz wykazywałoby szczególną wartość w odniesieniu do sprawców niepoczytalnych. Postanowienie o umorzeniu postępowania z tej przyczyny jest jego zdaniem dwuznaczne, ponieważ „społeczeństwo nie wie, czy podejrzany popełnił zarzucany mu czyn, lecz tylko z powodu swej niepoczytalności nie podlega odpowiedzialności karnej; czy też uwolniony zostaje od tej odpowiedzialności dlatego, że nie znaleziono podstaw do przypisania mu zarzuconego czynu"38.

${ }^{36}$ Wyr. SN z dnia 12 maja 1976 r., V KR 20/76. GP 1976, nr 22.

37 Zob. S. Steinborn: Prawomocność części orzeczenia..., s. 313 i wskazana tam literatura; por. art. 452 oraz art. 454 \$ 2 k.p.k. w brzmieniu obowiązującym przed 1 lipca 2015 r.

38 M. CIEślak: Koncepcja podziału procesu..., s. 398-399. Równocześnie Autor ten trafnie podnosił: „Prawda, że przyczyna umorzenia postępowania podana być musi w uzasadnieniu; ale uzasadnienie postanowienia na ogół nie dociera do świadomości społeczeństwa”. 


\section{Wnioski de lege ferenda}

\subsection{Uwagi ogólne}

Zaprezentowane wyżej rozważania prowadzą do wniosku, że koncepcja podziału procesu karnego na dwie fazy została w polskim piśmiennictwie odrzucona przedwcześnie, podczas gdy jej wcielenie w życie w wersji zaproponowanej przez R. Vouina mogłoby w znaczący sposób usprawnić przebieg postępowania jurysdykcyjnego, a równocześnie wzmocnić jego funkcję gwarancyjną, zdejmując z oskarżonego ciężar opierania swojej taktyki obrony na zasadzie „stawiania wszystkiego na jedną kartę”.

Nie powinno budzić wątpliwości, że ograniczenie rozpoznania sprawy wyłącznie do kwestii sprawstwa powinno być dla sądu bezwzględnie fakultatywne ${ }^{39}$. Zasadniczo powinno ono dotyczyć jedynie spraw o znacznym ciężarze gatunkowym, tym niemniej o wadze sprawy nie powinna decydować sama wysokość ustawowego zagrożenia karą przewidzianego za dane przestępstwo ${ }^{40}$ czy tryb jego ścigania. Komentowana instytucja nie powinna być wykorzystywana w sposób czysto instrumentalny, $\mathrm{w}$ związku z czym postanowienie w przedmiocie podziału postępowania każdorazowo powinno być szczegółowo uzasadniane, a przy tym zaskarżalne, tak żeby strony mogły zapoznać się z rzeczywistymi motywami podjęcia takiej decyzji procesowej oraz zażądać zweryfikowania przez sąd II instancji, czy podział jest w danym przypadku rzeczywiście uzasadniony i czy przyczyni się do sprawniejszego przeprowadzenia procesu.

Równie istotne jest, ażeby sprawę w jej obu fazach - o ile to oczywiście możliwie - rozpoznawał sąd w tym samym składzie. Skorzystanie z postulowanego rozwiązania ma przecież w założeniu służyć lepszemu zorganizowaniu postępowania głównego, a nie „przerzucaniu” odpowiedzialności za prawidłowy wynik sprawy o dużym stopniu skomplikowania na inne składy orzekające. Dodatkowo powierzenie przeprowadzenia drugiej fazy procesu tym samym sędziom powodowałoby, że w jej toku mogliby się oni opierać na wynikach postępowania dowodowego przeprowadzonego $\mathrm{w}$ pierwszej fazie, które wszak zachowują jeszcze $\mathrm{w}$ pamięci ${ }^{41}$. Na wypadek, gdyby rozpoznanie sprawy w tym samym składzie z jakiegoś powodu nie było jednak możliwe, sąd rozpoznający sprawę w fazie drugiej powinien mieć - analogicznie do tego, jak ma to miejsce $\mathrm{w}$ postępowaniu ponownym - możliwość uznania, że wbrew ustale-

39 Z kolei M. Wantoła uważa, że o podziale postępowaniu powinno się decydować na wniosek strony - M. WANTOŁA: Ciężar dowodu i obowiqzek..., s. 28.

${ }^{40}$ Tak również M. CieślaK: Koncepcja podziatu procesu..., s. 399, którego zdaniem: „[...] czasem nawet niewielkie przestępstwo jest symptomem wielkiego zagrożenia ze strony sprawcy i z tego tytułu czyni sprawę poważną".

41 Tak trafnie S. Steinborn: Prawomocność części orzeczenia..., s. 146. 
niom poczynionym $\mathrm{w}$ pierwszej fazie i stanowiącym podstawę faktyczną wyroku wstępnego oskarżony nie dopuścił się zarzuconego mu czynu albo że brak jest któregokolwiek z warunków dopuszczalności procesu. Przemawia za tym z jednej strony wzgląd na zasadę prawdy materialnej (art. 2 § 2 k.p.k.), a z drugiej na nieracjonalność czy wręcz niemożliwość wymierzania sankcji karnej w przypadku, w którym podmiot mający ją wymierzyć nie wierzy w sprawstwo podsądnego.

Warto zauważyć, że zawarte $\mathrm{w}$ wyroku wstępnym ustalenia faktyczne dotyczące sprawstwa nie byłyby wiążące dla sądu orzekającego w drugiej fazie również $\mathrm{w}$ razie braku w tym zakresie wyraźnej regulacji ustawowej (polegającej np. na odesłaniu do odpowiedniego stosowania w tej fazie art. $442 \S 1$ zd. 2 k.p.k.). Ewentualne związanie rozstrzygnięciem w przedmiocie sprawstwa (a przez to również wykładnią prawa i ustaleniami faktycznymi, których rozstrzygnięcie to stanowi konieczną konsekwencję) mogłoby wynikać jedynie z art. 8 § k.p.k. ${ }^{42}$. W przepisie tym mowa jest jednak wyłącznie o rozstrzygnięciach kształtujących prawo lub stosunek prawny, zwanych konstytutywnymi. W doktrynie prawa karnego procesowego wskazuje się, że konstytutywny charakter mają m.in. orzeczenia (a ściślej - zawarte w nich rozstrzygnięcia) skazujące, które poprzez obalenie konstytucyjnego domniemania niewinności kreują nową sytuację prawną ${ }^{43}$. W niemieckiej doktrynie prawa karnego procesowego przyjmuje się, że na podstawie wyroku skazującego czyjaś sytuacja prawna „niebycia karanym” zostaje zastąpiona przez sytuację prawną „bycia karanym”44. Tymczasem rozstrzygnięcie o sprawstwie oskarżonego nie obala jeszcze domniemania niewinności, ponieważ nie przesądza chociażby o winie w znaczeniu materialnoprawnym, a w konsekwencji również o odpowiedzialności karnej sprawcy czynu zabronionego. Ma ono w tym zakresie charakter zbliżony do postanowienia o umorzeniu postępowania i zasto-

42 Ibidem, s. 234; odmiennie P. HofMański: Częściowa prawomocność wyroków w procesie karnym. Probl. Prawa Karnego 1991, nr 17, s. 37-38, którego zdaniem związanie ustaleniami faktycznymi stanowiącymi podstawę horyzontalnie prawomocnego rozstrzygnięcia oraz przyjętą na jego potrzeby wykładnią może wynikać również z potrzeby zapewnienia orzeczeniu wewnętrznej spójności; por. IDEM: Samodzielność jurysdykcyjna sqadu karnego. Katowice 1988, s. 138-139; zob. również § 353 ust. 2 StPO, zgodnie z którym równocześnie $\mathrm{z}$ uchyleniem wyroku uchyleniu ulegają także ustalenia faktyczne tak dalece, jak dalece dotyczą naruszenia prawa, z powodu którego wyrok został uchylony („Gleichzeitig sind die dem Urteil zugrunde liegenden Feststellungen aufzuheben, sofern sie durch die Gesetzesverletzung betroffen werden, wegen deren das Urteil aufgehoben wird").

43 Por. J. HABER: Istota prawomocności w prawie procesowym karnym. "Zeszyty Prawnicze Polskiej Akademii Nauk" 1960, nr 1, s. 151; odmiennie m.in. E. PIENiążeK: Prejudycjalność orzeczeń w procesie karnym. Prok. i Pr. 2005, nr 12, 92-93.

${ }^{44}$ E. SснміDт: Lehrkommentar zur Strafprozeßordnung und zum Gerichtsverfassungsgesetz. Cz. I. Göttingen 1964, s. 47. Cyt. za: S. STEInborn: Prawomocność części orzeczenia..., s. 175. 
sowaniu środków zabezpieczających, w którego treści również przesądza się o sprawstwie oskarżonego (w przeciwnym bowiem wypadku podstawą zakończenia postępowania byłyby przesłanki wskazane w art. 17 $\S 1$ pkt 1 lub 2 in principio k.p.k.), a mimo to - z uwagi na stan niepoczytalności oskarżonego - nie dochodzi do przełamania domniemania niewinności. Innymi słowy, przy przyjęciu tej koncepcji orzeczeniem skazującym jest dopiero wyrok końcowy. Skoro więc wyrok dotyczący samego sprawstwa nie przesądza jeszcze kwestii winy, to a contrario ma on charakter wyłącznie deklaratoryjny. Tym samym z mocy art. $8 \S 1$ k.p.k. sądowi rozpoznającemu sprawę w pozostałym zakresie przysługuje pełna samodzielność jurysdykcyjna.

Niewykluczone również, że w celu respektowania wywodzonej $\mathrm{z}$ art. $402 \S 2$ oraz art. $404 \S 2$ zd. 2 in fine k.p.k. zasady niezmienności składu sądu w postępowaniu karnym sąd w ogóle nie powinien mieć możliwości prowadzenia drugiego $\mathrm{z}$ omawianych etapów $\mathrm{w}$ innym niż wcześniej składzie.

\subsection{Tryby konsensualne}

Problematyczna wydaje się możliwość podziału procesu karnego w postępowaniach toczących się $w$ tzw. trybach konsensualnych. Tym bardziej że z uwagi na ich nieistnienie w poprzednim półwieczu wątek ten nie był jak dotąd przedmiotem choćby pobieżnej analizy doktrynalnej. Komplikacji nie budzą te z porozumień procesowych, co do których decyzja zostaje podjęta najpóźniej na etapie postępowania przygotowawczego (skazanie bez rozprawy w trybie art. 335 \$ 1 i 2 k.p.k. oraz zezwolenie na dobrowolne poddanie się odpowiedzialności, o którym mowa w rozdziale 16 Kodeksu karnego skarbowego ${ }^{45}$ ), skoro decyzja o rozpoznaniu sprawy dwuetapowo może być $\mathrm{w}$ proponowanym tu ujęciu podejmowana wyłącznie przez sąd na etapie postępowania jurysdykcyjnego. Rozważenia wymagają jednak instytucje dobrowolnego poddania się odpowiedzialności w trybie art. 387 k.p.k. (zwana niekiedy „rozprawą skróconą" ${ }^{46}$ ) oraz wniosku o wydanie wyroku skazującego bez przeprowadzania postępowania dowodowego, o którym mowa w art. 338a k.p.k., możliwe do zastosowania właśnie w toku postępowania głównego.

Bliższa analiza przesłanek zastosowania tych trybów prowadzi do wniosku o niemożliwości ich połączenia z konstrukcją dwufazowego postępowania. Zgodnie z art. 387 \$2 i art. 343a §2 zd. 1 k.p.k. warunkiem uwzględnienia wniosku oskarżonego o wydanie wyroku skazującego i wymierzenie mu określonego środka reakcji karnej bez przeprowadzania

45 Ustawa z dnia 10 września 1999 r. - Kodeks karny skarbowy, Dz.U. 2020, poz. 19.

46 S. Waltoś, P. Hofmański: Proces karny. Zarys systemu. Wyd. 11. Warszawa 2013, s. 513. 
postępowania dowodowego jest w obu przypadkach m.in. przyjęcie przez sąd, że okoliczności popełnienia przestępstwa i wina (w znaczeniu procesowym) nie budzą wątpliwości. Już zatem warunek niewątpliwej winy oskarżonego wymaga od sądu ustalenia okoliczności przynależnych do obu faz postępowania głównego (z jednej strony sprawstwa, a z drugiej społecznej szkodliwości czynu czy winy w znaczeniu materialnoprawnym), co uniemożliwia uwzględnienie obu wniosków w drodze wyroku wstępnego. Poza tym istotą tych trybów jest przecież przypisanie oskarżonemu popełnionego czynu i wymierzenie mu za to określonej sankcji, co wszak nie jest częścią pierwszej fazy podzielonego postępowania (nie kończy się ona skazaniem, o które wnosi oskarżony).

Powyższe materialnoprawne warunki dopuszczalności uwzględnienia obu rodzajów wniosków mogą być spełnione w drugiej fazie procesu, która ze swej istoty powinna się kończyć właśnie ustaleniem winy w znaczeniu procesowym i wymierzeniem sprawcy przestępstwa określonej kary lub innego środka, co prima facie mogłoby uzasadniać tezę o możliwości łącznego zastosowania konstrukcji porozumienia procesowego i wyroku końcowego. Tyle tylko, że z kolei na tym etapie postępowania niemożliwe już będzie spełnienie warunków o charakterze procesowym. Oskarżony może - w zależności od trybu - złożyć wniosek o wydanie wyroku skazującego do chwili zakończenia pierwszego przesłuchania wszystkich oskarżonych na rozprawie głównej (art. 387 \$1 zd. 1 k.p.k.) albo przed doręczeniem mu zawiadomienia o terminie rozprawy (art. 338a zd. 1 k.p.k.). Oba terminy zdążą już przecież upłynąć, skoro postępowanie toczyło się wcześniej w zakresie sprawstwa oskarżonego, a zatem przesłuchano oskarżonych i doręczono im zawiadomienia o terminie rozprawy. W odniesieniu do drugiego z nich warto zauważyć, że podział postępowania głównego na dwie części zasadniczo ma charakter wyłącznie techniczny (służy sprawniejszemu rozpoznaniu sprawy), w związku z czym podjęcie przez sąd decyzji o jego rozbiciu nie oznacza, że pierwszy termin rozprawy poświęcony kwestiom innym aniżeli sprawstwo jest pierwszym terminem rozprawy w rozumieniu art. 338a zd. 1 k.p.k. Obie fazy składają się łącznie na jedną (tę samą) rozprawę główną, w związku z czym wydanie wyroku wstępnego nie powoduje „odżycia” terminu do skutecznego złożenia wniosku o wydanie wyroku skazującego w omawianym trybie konsensualnym ${ }^{47}$.

47 Zob. wyr. SN z dnia 7 czerwca 2018 r., V KK 172/18. LEX nr 2509700, w którym Sąd Najwyższy stanął na stanowisku, zgodnie z którym termin do złożenia wniosku w trybie art. 338a k.p.k. „odżywa” na skutek uchylenia zaskarżonego wyroku i przekazania sprawy sądowi I instancji do ponownego rozpoznania; tak też D. ŚwIEcki: Czynności procesowe obrońcy $i$ petnomocnika $w$ sprawach karnych. Wyd. 3. Warszawa 2015, s. 131. 
Podsumowując, zastosowanie mechanizmu swoistej fragmentacji postępowania jurysdykcyjnego nie może nastąpić w żadnym z obecnie obowiązujących postępowań toczących się w tzw. nurcie konsensualnym. Wniosek ten jest zresztą dość oczywisty, jeżeli weźmie się pod uwagę sens obu konstrukcji. $Z$ analizy przesłanek zawarcia poszczególnych porozumień procesowych wynika, że istota konsensualnych sposobów zakończenia procesu karnego sprowadza się do możliwości ich stosowania w sprawach, w których stan faktyczny zasadniczo nie budzi żadnych wątpliwości, podczas gdy prezentowana w tej pracy koncepcja podziału procesu karnego na dwie fazy ma za zadanie ułatwić rozstrzyganie spraw o znacznym stopniu skomplikowania.

\section{3. Środki zaskarżenia}

Przechodząc do kwestii środków zaskarżenia, za optymalne należy uznać przyznanie stronie prawa do zaskarżenia wyroku wstępnego od razu po jego wydaniu (ściślej: po jego doręczeniu wraz z uzasadnieniem), a nie - jak proponuje się niekiedy $\mathrm{w}$ piśmiennictwie ${ }^{48}$ - dopiero po wydaniu wyroku końcowego. Po pierwsze, kwestia sprawstwa co do zasady nie powinna budzić wątpliwości w czasie rozstrzygania w drugiej fazie, żeby strony mogły skupić się na udowadnianiu okoliczności mających znaczenie np. dla poczytalności czy stopnia winy, czemu bez wątpienia nie służyłoby równoczesne prowadzenie postępowania odwoławczego w przedmiocie sprawstwa. Po drugie wreszcie, strona niepewna co do tego, że pozytywny dla niej wyrok wydany w pierwszej fazie zostanie utrzymany w mocy przez sąd II instancji, w rzeczywistości nie ma swobody w zakresie udowadniania pozostałych okoliczności, obawiając się o późniejsze wykorzystanie jej twierdzeń w postępowaniu ponownym dotyczącym sprawstwa, przez co formalnie dwufazowe postępowanie jurysdykcyjne nie spełniłoby swojej podstawowej funkcji.

Nie do końca jasne jest, czy orzeczenie sądu odwoławczego wydane $\mathrm{w}$ następstwie rozpoznania apelacji od wyroku wstępnego jest wyrokiem kończącym postępowanie w rozumieniu art. 519 zd. 1 k.p.k. Z jednej strony wykonanie wyroku o uznaniu oskarżonego za sprawcę czynu każdorazowo uzależnione jest od wydania również wyroku końcowego, co prze-

${ }^{48}$ M. CIEŚLAK: Koncepcja podziału procesu..., s. 400, który równocześnie wskazuje, że „Do rozważenia byłaby jednak kwestia przyznania wyłącznie oskarżonemu prawa do zaskarżenia orzeczenia uznającego jego winę - niezależnie od toczącej się fazy drugiej procesu". Z kolei M. Wantoła jedynie nie wyklucza zastrzeżenia (tym samym nie uznając tego za konieczne), że postępowanie dotyczące okoliczności wpływających na wymiar kary i innych środków mogłoby się toczyć dopiero po uprawomocnieniu się wyroku przesądzającego o odpowiedzialności karnej oskarżonego - M. WANTOŁA: Ciężar dowodu i obowiq̨zek..., s. 28. 
mawiałoby za uznaniem, że kasacja nie przysługuje na drugoinstancyjny wyrok o utrzymaniu w mocy wyroku wstępnego przesądzającego kwestię sprawstwa w sposób pozytywny, skoro postępowanie w przedmiocie odpowiedzialności karnej oskarżonego nie dobiegło jeszcze końca. Na tle wyroku sądu II instancji, którego mocą uchylono zaskarżony wyrok jedynie w części dotyczącej kary, Sąd Najwyższy przyjął, że „[...] sformułowanie »kończące postępowanie « użyte w art. 519 k.p.k. nie dotyczy zakończenia postępowania $\mathrm{w}$ danej instancji, lecz całego postępowania stanowiącego przedmiot procesu"49. Skoro więc według zwolenników tego poglądu postępowania nie kończy nawet orzeczenie o winie, to a maiori ad minus nie kończyłoby go również orzeczenie o samym sprawstwie. Z drugiej strony w piśmiennictwie podnosi się, iż w przywołanym przepisie chodzi wyłącznie o prawomocność formalną, w związku z czym z punktu widzenia dopuszczalności kasacji istotne jest jedynie, aby orzeczenie nie było zaskarżalne za pomocą zwyczajnych środków odwoławczych, a zatem że co do zasady niedopuszczalne jest kontynuowanie postępowania dotyczącego rozstrzygniętej kwestii. Innymi słowy, przez orzeczenie kończące postępowanie należy rozumieć orzeczenie, które prawnie wyłącza możliwość dalszego zwykłego toku instancyjnego, a nie jakiegokolwiek postępowania $\mathrm{w}$ ogóle ${ }^{50}$. De lege lata $\mathrm{z}$ sytuacją taką bez wątpienia mamy do czynienia w przypadku horyzontalnie prawomocnego rozstrzygnięcia o winie, jednakże wyglądałaby ona niemal identycznie w odniesieniu do prawomocnego wyroku wstępnego.

Powyższe wątpliwości nie dotyczą z kolei orzeczeń kasatoryjnych, jak również części orzeczeń afirmatywnych i reformatoryjnych. Rozstrzygnięcia o uchyleniu zaskarżonego orzeczenia i przekazaniu sprawy do rozpoznania sądowi I instancji powinny być traktowane tak samo jak tego typu wyroki kasatoryjne wydane w wyniku rozpoznania apelacji dotyczącej zwyczajnego, „pełnego” wyroku, od których właściwym nadzwyczajnym środkiem zaskarżenia jest uregulowana w rozdziale 55a k.p.k. skarga na wyrok sądu odwoławczego. Co zaś tyczy się orzeczeń afirmatywnych wydanych

49 Postanowienie SN z dnia 16 maja 2007 r., III KK 46/06. OSNKW 2008, nr 4, poz. 24, s. 1 z aprobującą glosą K. WoźnIEwsKIEGo: Niedopuszczalność kasacji $w$ świetle ponownego postępowania. Glosa do postanowienia SN z 16 maja 2007 r., III KK 46/06. GSP 2008, nr 2, s. 121-128, częściowo krytyczną W. KociubIŃsKIEGo: Glosa do postanowienia z dnia 16 maja 2007 r., III KK 46/06. PS 2010, nr 7-8, s. 197-202 oraz krytyczną M. KoNDRACKIEGO: Glosa do postanowienia Sądu Najwyższego z 16 maja 2007 r., III KK 46/06. Pal. 2010, nr 5-6, s. 275-278; tak również postanowienie SN z dnia 17 stycznia 2012 r., V KZ 79/11. OSNKW 2012, nr 3, poz. 31, s. 49, w którym wskazano, że: „Orzeczenie sądu odwoławczego musi mieć zatem status prawomocności oraz definitywności rozstrzygnięcia co do istoty procesu, aby mogło być zaskarżone kasacją".

50 S. Steinborn: Prawomocność części orzeczenia..., s. 640-642; Z. Doda: Rewizja nadzwyczajna w polskim procesie karnym. Warszawa 1972, s. 120-121. 
w postępowaniu apelacyjnym zainicjowanym skargą na wyrok wstępny, to mogą one dotyczyć wyłącznie wyroków pozytywnie przesądzających kwestię sprawstwa, a wtedy odnoszą się do nich wszystkie wskazane wyżej wątpliwości. Wyrok uniewinniający albo umarzający postępowanie nigdy nie może być wstępny, ponieważ negatywne przesądzenie kwestii sprawstwa lub dopuszczalności procesu czyni bezprzedmiotowym dalsze rozpoznawanie sprawy w jakimkolwiek zakresie. Skoro zatem pierwszoinstancyjne rozstrzygnięcie uniewinniające albo umarzające jest zawsze wyrokiem „pełnym”, to oczywiste jest, że taki sam charakter musi mieć dotyczący go afirmatywny wyrok sądu II instancji, który tym samym kończy postępowanie i podlega zaskarżeniu w drodze kasacji. Jeszcze inaczej przedstawia się sytuacja wyroków reformatoryjnych. Jeżeli sąd I instancji uznał oskarżonego za sprawcę czynu zabronionego i wydał wobec niego wyrok wstępny, to do reformatoryjnego wyroku sądu odwoławczego (polegającego np. na zmianie przyjętej przez sąd a quo kwalifikacji prawnej czynu) odnoszą się wszystkie wskazane wyżej wątpliwości związane z wykładnią art. 519 zd. 1 k.p.k. Te same problemy pojawią się również w razie ustalenia $\mathrm{w}$ toku postępowania apelacyjnego, że w kontrolowanym orzeczeniu niesłusznie uznano, iż oskarżony nie jest sprawcą zarzuconego mu czynu, kiedy to sąd odwoławczy - jeżeli oczywiście uzna za uzasadnione podzielenie postępowania na dwie fazy - zmuszony będzie wydać reformatoryjny wyrok wstępny. Wątpliwości nie budzi z kolei odwrotny układ procesowy, w którym sąd ad quem uznaje orzeczenie o sprawstwie oskarżonego za nietrafne i w związku z tym wydaje „pełne” - i przez to podlegające zaskarżeniu $\mathrm{w}$ drodze kasacji - orzeczenie uniewinniające bądź umarzające postępowanie.

Przyjęcie, że orzeczenie sądu odwoławczego wydane w następstwie rozpoznania apelacji od wyroku wstępnego nie jest wyrokiem kończącym postępowanie w rozumieniu wskazanego wyżej przepisu oznaczałoby, że strona nigdy nie mogłaby podnosić w postępowaniu kasacyjnym zarzutów związanych z rozstrzygnięciem o sprawstwie. Wyrok końcowy formalnie jest przecież orzeczeniem odrębnym (niezależnym) od wyroku wstępnego, w związku z czym w dotyczącej go kasacji strona nie mogłaby niejako przy okazji - kwestionować prawomocnego orzeczenia o sprawstwie $^{51}$.

Jeśli jednak przyjmiemy, że opisane wyżej orzeczenie sądu odwoławczego jest wyrokiem kończącym postępowanie, to z uwagi na przedmiotowe ograniczenie kasacji na korzyść oskarżonego, o którym mowa

${ }^{51} \mathrm{~W}$ odniesieniu do problematyki prawomocności horyzontalnej orzeczenia o winie podobnie S. Steinborn: Prawomocność części orzeczenia..., s. 644. Autor ten wskazuje, że w postępowaniu kasacyjnym dotyczącym orzeczenia o karze strona mogłaby co najwyżej podnieść zarzut naruszenia w postępowaniu ponownym art. 442 § 1 zd. 2 k.p.k. 
w art. $523 \S 2$ k.p.k. (wymóg skazania oskarżonego na karę pozbawienia wolności bez warunkowego zawieszenia jej wykonania), należałoby wprowadzić szczególną regulację dotyczącą biegu terminu do wniesienia kasacji na wyrok wydany w pierwszej fazie. Bez orzeczenia o karze nie wiadomo przecież jeszcze, czy zostały spełnione warunki pozwalające na wniesienie kasacji opartej na uchybieniach niewskazanych w art. 439 § 1 k.p.k., czy też może ostatecznie sąd odstąpi od wymierzenia kary, poprzestanie na orzeczeniu środków karnych (lub ewentualnie innych środków), wymierzy oskarżonemu grzywnę lub karę ograniczenia wolności bądź też zawiesi wykonanie orzeczonej kary pozbawienia wolności, w związku z czym termin do zaskarżenia obu wyroków (najlepiej zresztą łącznego) powinien rozpocząc swój bieg dopiero z chwilą doręczenia wyroku koncowego wraz z uzasadnieniem. Tym bardziej że orzeczenie o sprawstwie oskarżonego nie musi się nawet kończyć jego skazaniem, ponieważ sąd w drugiej fazie może uznać np., że sprawca był niepoczytalny albo że z innych przyczyn nie można przypisać mu winy.

Wprawdzie zarysowany wyżej problem nie dotyczy kasacji opartych wyłącznie na jednej z bezwzględnych przyczyn odwoławczych (oczywiście z wyjątkiem opisanej w art. 439 § 1 pkt 5 k.p.k. sytuacji polegającej na wymierzeniu oskarżonemu kary lub środka nieznanych ustawie, ewentualnie również wskazanej w art. 439 § 1 pkt 7 k.p.k. sprzeczności w treści orzeczenia uniemożliwiającej jego wykonanie, która zasadniczo dotyczyć będzie wyłącznie niezgodności pomiędzy rozstrzygnięciami w przedmiocie kary i innych środków reakcji karnej), tym niemniej niewskazane byłoby moim zdaniem przyjęcie rozwiązania, zgodnie z którym początek biegu terminu do wniesienia nadzwyczajnego środka odwoławczego zależałby wyłącznie od tego, jakiego uchybienia miałby on dotyczyć. Równie wątpliwe byłoby przyznanie stronie uprawnienia do dwukrotnego wniesienia kasacji na to samo orzeczenie, z których pierwsza dotyczyłaby wyłącznie uchybień stanowiących bezwzględne przyczyny odwoławcze i byłaby możliwa do wniesienia w terminie liczonym na zasadach ogólnych (a zatem w praktyce przed wydaniem wyroku końcowego), zaś druga odnosiłaby się do wszelkich innych wadliwości orzeczenia sądu ad quem, a możliwość jej wniesienia byłaby uzależniona od uprzedniego wydania wyroku prawomocnie kończącego drugą fazę postępowania (arg. ex art. 522 k.p.k.).

\subsection{Podsumowanie}

Przedstawione wyżej rozważania prowadzą do wniosku, że ustawodawca powinien wprowadzić do polskiego porządku prawnego elementy koncepcji dwufazowego procesu karnego w zarysowanej wyżej wersji, w związku z czym postuluję przeprowadzenie następujących zmian w Kodeksie postępowania karnego: 
1) w art. 99a $§ 1$ nadać następujące brzmienie:

„§1. Uzasadnienie wyroku sądu pierwszej instancji, w tym wyroku wstępnego, wyroku nakazowego i wyroku łącznego, oraz wyroku sądu odwoławczego i wyroku wydanego w postępowaniu o wznowienie postępowania sporządza się na formularzu według ustalonego wzoru.";

2) w art. $339 \mathrm{w} \S 3 \mathrm{w}$ pkt 7 kropkę zastąpić średnikiem i po pkt 7 dodać pkt 8 w następującym brzmieniu:

„8) wydania wyroku wstępnego.”;

3) po art. 380 dodać art. 380a w następującym brzmieniu:

„Art. 380a. §1. W uzasadnionych przypadkach sąd może postanowić o rozpoznaniu sprawy jedynie w zakresie ustalenia, czy oskarżony popełnił zarzucony mu czyn zabroniony (wyrok wstępny).

$\S 2$. Na postanowienie, o którym mowa w $§ 1$, przysługuje zażalenie.

$\S 3$. W razie wydania postanowienia, o którym mowa $\mathrm{w} \S 1$, wyrok w pozostałym zakresie (wyrok końcowy) może zapaść dopiero po uprawomocnieniu się wyroku wstępnego. Przepis art. $442 \S 1$ zdanie drugie stosuje się odpowiednio.

§4. Sąd wydaje wyrok końcowy w tym samym składzie, w którym wydał wyrok wstępny, chyba że nie jest to możliwe.";

4) w art. 413 po $\S 1$ dodać $\S 1$ a w następującym brzmieniu:

„\$1a. Wyrok wstępny powinien ponadto zawierać dokładne określenie popełnionego przez oskarżonego czynu oraz jego kwalifikację prawną.";

5) w art. 524 po $\S 1$ dodać $§ 1 \mathrm{a}$ w następującym brzmieniu:

„\$1a. W przypadku wydania wyroku wstępnego termin do wniesienia kasacji biegnie od dnia doręczenia wyroku końcowego z uzasadnieniem".

Próbując wystarczająco szeroko omówić powyższą propozycję, w zakresie, w jakim nie znajduje ona potwierdzenia wprost we wcześniejszych fragmentach niniejszej pracy, należy rozpocząc od spostrzeżenia, że najwłaściwszym miejscem na regulację zawartą w art. 380a byłby rozdział 43 k.p.k. poświęcony ogólnym przepisom o rozprawie głównej. Do rozważenia byłoby wprawdzie jej umiejscowienie w rozdziale 47 k.p.k. dotyczącym wyrokowania (skoro dotyczy ona właśnie różnych rodzajów wyroków), jednakże warto mieć na uwadze, że § 1 i 2 proponowanego przepisu dotyczą bezpośrednio orzeczenia wydawanego $\mathrm{w}$ formie postanowienia, co z oczywistych względów prowadziłoby do zaburzenia wewnętrznej spójności tej części ustawy procesowej. Zamieszczenie art. 380a w przepisach ogólnie traktujących o rozprawie głównej oznaczałoby również, że postępowanie dwuetapowe nie pełni funkcji nowego typu postępowania szczególnego, ale stanowi regulację niejako „przednawiasową”, którą 
z powodzeniem można stosować również w sprawach z oskarżenia prywatnego czy w sprawach podlegających orzecznictwu sądów wojskowych.

Wyrok wstępny, oprócz konstytutywnych elementów każdego wyroku, powinien zawierać jedynie rozstrzygnięcie, że oskarżony popełnił zarzucony mu czyn (tj. zrealizował jego znamiona), a także jego opis i przyjętą przez sąd kwalifikację prawną. Wprowadzenie art. 413 § 1a przed $\$ 2$ akcentowałoby, że wyrok wstępny nie jest wyrokiem skazującym, albowiem taki charakter ma dopiero wyrok końcowy. Stąd też w treści tego orzeczenia mowa jest jedynie o czynie, który oskarżony popełnił, ponieważ jego przypisanie może nastąpić dopiero w wyroku skazującym. Jednocześnie, skoro wyrok końcowy jest „zwykłym” wyrokiem skazującym, to oczywiste jest, że nie ma potrzeby odrębnego regulowania jego treści. Co zaś tyczy się uzasadnienia obu typów wyroków, to za wystarczające należy uznać zmodyfikowanie treści art. 99a § 1 k.p.k. poprzez poszerzenie katalogu wymienionych w tym przepisie rodzajów wyroków o wyrok wstępny (a w dalszej kolejności oczywiście zmianę Rozporządzenia Ministra Sprawiedliwości z dnia 28 listopada 2019 r. w sprawie wzorów formularzy uzasadnień wyroków oraz sposobu ich wypełniania ${ }^{52}$ ).

Proponowane rozwiązanie wprowadzałoby wyjątek od art. 110 k.p.k., skoro narada i głosowanie nad wyrokiem wstępnym ze swej istoty nie może odbywać się co do winy, kary i innych wskazanych w tym przepisie rozstrzygnięć, jak również przewidywałoby poważny wyłom od zakodowanej $\mathrm{w}$ tym przepisie reguły, zgodnie $\mathrm{z}$ którą głosowanie $\mathrm{w}$ ramach każdej z kwestii (w tym co do winy w znaczeniu procesowym) powinno przybierać charakter totalny i nie może dotyczyć poszczególnych części takiego rozstrzygnięcia (a zatem m.in. samego sprawstwa) ${ }^{53}$. Tym niemniej relacja pomiędzy art. 110 k.p.k. (przepis ogólny) a art. 380a §1 (przepis szczególny) wydaje się na tyle oczywista, że nie wymagałaby ze strony ustawodawcy jakiejkolwiek dodatkowej interwencji.

Proponowany w niniejszej pracy podział postępowania głównego, co podkreślano już wcześniej, miałby w istocie jedynie techniczny charakter, w związku z czym poszczególne etapy postępowania nie różniłyby się - ani od siebie, ani od jednofazowego postępowania - w zakresie stosowania $\mathrm{w}$ ich toku naczelnych zasad procesu karnego, celu ich prowadzenia, pozycji uczestników, reguł rządzących postępowaniem dowodowym, możliwych do zastosowania przez sąd lub przewodniczącego środków przymusu itd. Postępowanie główne, mimo że prowadzone dwuetapowo, byłoby nadal zwyczajnym postępowaniem karnym, w związku z czym zakres gwarancji procesowych stron i innych jego uczestników nie powinien

52 Dz.U. poz. 2349.

53 Zob. S. ŚLIwiński: Polski proces karny przed sądem powszechnym. Zasady ogólne. Warszawa 1961, s. 488-491. 
być zależny od tego, czy sąd zdecydował się rozpoznać daną sprawę od razu w całości, czy też postanowił skupić się kolejno na analizie sprawstwa i wszelkich innych kwestii.

W sugerowanej treści art. 380a §1 świadomie zaniechano wskazania ram czasowych, w których sąd mógłby podejmować decyzję o podziale postępowania na dwie fazy, co a contrario oznacza, że teoretycznie podjęcie takiej decyzji mogłoby nastąpić w każdym momencie do czasu zamknięcia przewodu sądowego. Wynika to z założenia, że nie sposób in abstracto ustalić, na którym etapie postępowania rozpoznający sprawę sąd mógłby powziąć wątpliwość co do celowości jego całościowego (jednoetapowego) prowadzenia. Pozostaje wyrazić nadzieję, że w praktyce rozstrzygnięcie o podziale postępowania - $\mathrm{w}$ razie wprowadzenia przez ustawodawcę możliwości jego wydawania - następować będzie na możliwie najwcześniejszym etapie postępowania głównego, w tym zwłaszcza na posiedzeniu przygotowawczym, o którym mowa w art. 349 k.p.k. (stąd też postulowana zmiana w zakresie art. 339 § 3 k.p.k., polegająca na zezwoleniu prezesowi sądu, jeżeli dostrzeże potrzebę wydania wyroku wstępnego od razu po wniesieniu sprawy do sądu, skierowania sprawy na posiedzenie), tym niemniej nie sposób wykluczyć możliwości dostrzeżenia takiej potrzeby dopiero po otwarciu przewodu sądowego. Wydaje się, że im później zostanie ona dostrzeżona, tym - z uwagi na stan zaawansowania przeprowadzonego postępowania dowodowego - więcej argumentów przemawiać będzie za dokończeniem postępowania w dotychczasowym trybie.

Wedle postulowanego unormowania skorzystanie przez sąd z możliwości wydania wyroku wstępnego byłoby uzależnione od wystąpienia „uzasadnionego przypadku”. Choć zdaję sobie sprawę z wielu negatywnych stron stosowania techniki legislacyjnej opartej na odwoływaniu się do zwrotów niedookreślonych, to jednak uważam, że w tym konkretnym przypadku ewentualne korzyści z tego płynące przemawiają za wyższością takiego rozwiązania nad metodą opartą na kazuistycznym, a przez to zbyt sztywnym określeniu przesłanek stosowania tej instytucji. Nie sposób na tym etapie przewidzieć wszystkich układów procesowych, w których celowe będzie skorzystanie z mechanizmu dwufazowego postępowania głównego, w związku z czym zadanie odszukania katalogu tych sytuacji należy pozostawić judykaturze (w tym zwłaszcza Sądowi Najwyższemu i sądom rozpoznającym zażalenia wnoszone w trybie art. 380a §2). Jedynie na marginesie warto zwrócić uwagę, że sformułowania takie jak „uzasadniony przypadek” czy „uzasadniony wypadek” występują w ustawie procesowej również de lege lata (m.in. w art. 73 § 2 i 3, art. 253 § 3, art. 310 §, art. 378a $\S 1$, art. 589zr $\S 1$ zd. 2 i art. $607 \mathrm{~m} \S 2$ zd. 1 k.p.k.).

Najwięcej problemów przy okazji redagowania proponowanego brzmienia art. 380a sprawiło, rzecz jasna, opisanie w języku prawnym 
sfery sprawstwa, które to wyrażenie jest przecież na gruncie prawa karnego procesowego używane wyłącznie w doktrynie i judykaturze. Uznając za niewskazane wprowadzanie do ustawy procesowej całkowicie nowego pojęcia, a równocześnie starając się zachować syntetyczność tworzonego przepisu, przyjąłem, że „uznać czyjeś sprawstwo” znaczy tyle, co „rozstrzygnać, iż dana osoba popełniła zarzucony jej w akcie oskarżenia czyn zabroniony". Czyn zabroniony to zgodnie z art. 115 \$1 k.k. zachowanie o znamionach określonych w ustawie karnej. Jak wynika $\mathrm{z}$ art. 1 \$2 i 3 k.k., nie każdy czyn zabroniony stanowi przestępstwo, ponieważ ustalenie, iż ktoś jest „sprawcą czynu zabronionego”, nie znaczy jeszcze, że czyn ten był równocześnie zawiniony oraz społecznie szkodliwy w stopniu wyższym niż znikomy. Myśl tę wyraźniej wysłowiono w art. 53 § 1 k.k.s., zgodnie z którym „Czyn zabroniony jest to zachowanie o znamionach określonych w kodeksie, chociażby nie stanowiło ono przestępstwa skarbowego lub wykroczenia skarbowego". Należy jednak zauważyć, że pojęcie „sprawstwa” występuje z kolei w języku ustaw z zakresu prawa karnego materialnego (art. 18 § 1 i art. 19 § 1 k.k. oraz art. 9 § 1 k.k.s.), w związku z czym posłużenie się nim również $\mathrm{w}$ art. 380a mogłoby niepotrzebnie sugerować, że wydanie wyroku wstępnego nie jest możliwe w przypadku oskarżenia o czyn popełniony w jednej z tzw. niesprawczych form współdziałania przestępnego (podżegania czy pomocnictwa) albo przez osobę zajmującą się cudzymi sprawami gospodarczymi, która zgodnie z art. 9 $\S 3$ k.k.s. odpowiada verba legis ,jak sprawca”, co oczywiście nie byłoby rozwiązaniem racjonalnym. Opisywane niuanse terminologiczne zaważyły na przyjęciu, że w drodze wyroku wstępnego sąd powinien rozstrzygać jedynie o tym, czy oskarżony popełnił zarzucony mu czyn zabroniony.

\section{Bibliografia}

\section{Literatura}

ANDREJEW I.: Ustawowe znamiona przestępstwa. Warszawa 1959.

Berutowicz W.: Posteppowanie cywilne w zarysie. Wyd. 3. Warszawa 1984.

CIEŚLAK M.: Koncepcja podziału procesu karnego na dwie fazy (jej miejsce i perspektywy $w$ prawie karnym). PiP 1968, z. 3.

DodA Z.: Rewizja nadzwyczajna w polskim procesie karnym. Warszawa 1972.

GARDOCKI L.: Prawo karne. Wyd. 21. Warszawa 2019.

Góra-BŁaszczyкowska A. W: Kodeks postępowania cywilnego. T. IA. Komentarz. Art. 1-42412. Red. IDEM. Wyd. 3. Warszawa 2020.

Gudowski J. W: Kodeks postępowania cywilnego. Komentarz. T. II. Postępowanie rozpoznawcze. Red. T. ERECIŃsKI. Wyd. 5. Warszawa 2016.

HABER J.: Istota prawomocności w prawie procesowym karnym. „Zeszyty Prawnicze Polskiej Akademii Nauk" 1960, nr 1. 
Hofmański P.: Częściowa prawomocność wyroków w procesie karnym. Probl. Prawa Karnego 1991, nr 17.

HoFMAŃsKi P.: Samodzielność jurysdykcyjna sądu karnego. Katowice 1988.

HofmańsKi P., SADZIK E., ZgryzeK K. W: Kodeks postępowania karnego. T. II. Komentarz do artykułów 297-467. Red. P. HofmańsKi. Wyd. 4. Warszawa 2011.

KLEJNOwsKa M.: Wyjątki od regut rozkładu ciężaru dowodu w procesie karnym. „Ius et administratio" 2004, z. 1.

KocIUBIŃsKI W.: Glosa do postanowienia z dnia 16 maja 2007 r., III KK 46/06. PS 2010, nr 7-8.

Kondracki M.: Glosa do postanowienia Sądu Najwyższego z 16 maja 2007 r., III KK 46/06. Pal. 2010, nr 5-6.

Markiewicz K. W: Kodeks postępowania cywilnego. T. I. Komentarz. Art. 1-366. Red. A. Marciniak, K. Piasecki. Wyd. 7. Warszawa 2016.

MurzynowsKi A.: Refleksje na temat nauki procesu karnego w Polsce Ludowej. Pal. 1977, nr 1.

PieniążEK E.: Prejudycjalność orzeczeń w procesie karnym. Prok. i Pr. 2005, nr 12.

Prawo karne materialne. Część ogólna i szczególna. Red. M. BoJARsKI. Wyd. 7. Warszawa 2017.

Rolland M.: La scission du procès en deux phases. W: L'individualisation des mesures prises à l'égard du délinquant. Paryż 1954.

SAWICKI J.: O nowej ochronie społecznej. PiP 1955, z. 1.

SCHMIDT E.: Lehrkommentar zur Strafprozeßordnung und zum Gerichtsverfassungsgesetz. Cz. I. Göttingen 1964.

SkorupKa J. W: Proces karny. Red. IDEM. Wyd. 2. Warszawa 2018.

STEINBORN S.: Prawomocność części orzeczenia $w$ procesie karnym. Warszawa 2011.

ŚLIWIŃSKI S.: Polski proces karny przed sądem powszechnym. Zasady ogólne. Warszawa 1961.

ŚwIECKI D.: Czynności procesowe obrońcy i petnomocnika $w$ sprawach karnych. Wyd. 3. Warszawa 2015.

ŚwIECKI D.: Konstrukcja apelacji jako środka odwoławczego w procesie karnym. Warszawa 2018.

Vouin R.: La division du procès pénal en deux phases. W: L'individualisation des mesures prises à l'égard du délinquant. Paryż 1954.

Waiblinger M.: Der rechtliche Charakter und die Bedeutung der Schuldigerklärung im Strafprozeß. Das Problem der Teilrechtskraft. W: Strafprozess und Rechtsstaat. Festschrift zum 70. Geburtstag von Prof. Dr. H.F. Pfenninger. Zurych 1956.

Waltoś S., Hofmański P.: Proces karny. Zarys systemu. Wyd. 11. Warszawa 2013.

WantoŁA M.: Ciężar dowodu i obowiazek dowodzenia okoliczności wptywających na wymiar kary $i$ innych środków reakcji karnej. CPKNP 2019, poz. 9 (wyd. elektroniczne).

WARYLEWSKI J.: Kierunki i szkoły $w$ nauce prawa karnego. W: System Prawa Karnego. T. I. Zagadnienia ogólne. Red. A. MAREK. Warszawa 2010.

WAŻNy A. W: Kodeks postępowania karnego. Komentarz. Red. A. SAKowicz. Wyd. 8. Warszawa 2018. 
WoźNIEwsкi K.: Niedopuszczalność kasacji $w$ świetle ponownego postępowania. Glosa do postanowienia SN z 16 maja 2007 r., III KK 46/06. GSP 2008, nr 2.

WRóBeL W.: O domniemaniach $w$ zakresie przesłanek odpowiedzialności karnej. „Zeszyty Naukowe Uniwersytetu Jagiellońskiego” 2006, nr 5.

Wróbel W., Zoll A.: Polskie prawo karne. Część ogólna. Kraków 2013.

\section{Akty prawne}

Ustawa z dnia 17 listopada 1964 r. - Kodeks postępowania cywilnego, Dz.U. 2019, poz. 1460 ze zm.

Ustawa z dnia 6 czerwca 1997 r. - Kodeks karny, Dz.U. 2019, poz. 1950 i 2128.

Ustawa z dnia 6 czerwca 1997 r. - Kodeks postępowania karnego, Dz.U. 2020, poz. 30.

Ustawa z dnia 10 września 1999 r. - Kodeks karny skarbowy, Dz.U. 2020, poz. 19.

Ustawa z dnia 19 lipca 2019 r. o zmianie ustawy - Kodeks postępowania karnego oraz niektórych innych ustaw, Dz.U. poz. 1694.

Ustawa z dnia 28 października 2002 r. o odpowiedzialności podmiotów zbiorowych za czyny zabronione pod groźbą kary, Dz.U. 2019, poz. 628 i 1214.

Rozporządzenie Ministra Sprawiedliwości z dnia 28 listopada 2019 r. w sprawie wzorów formularzy uzasadnień wyroków oraz sposobu ich wypełniania, Dz.U. poz. 2349.

\section{Orzecznictwo}

Wyr. SN z dnia 12 maja 1976 r., V KR 20/76. GP 1976, nr 22.

Wyr. SN z dnia 7 czerwca 2018 r., V KK 172/18. LEX nr 2509700.

Post. SN z dnia 16 maja 2007 r., III KK 46/06. OSNKW 2008, nr 4, poz. 24.

Post. SN z dnia 17 stycznia 2012 r., V KZ 79/11, OSNKW 2012, nr 3, poz. 31, s. 49.

Wyr. SA w Warszawie z dnia 13 marca 2003 r., II AKa 87/03. OSA 2003, nr 12, poz. 119.

Post. SA w Lublinie z dnia 17 listopada 2010 r., II AKz 485/10. LEX nr 785264. 